\title{
The challenges for molecular nutrition research 1: linking genotype to healthy nutrition
}

\author{
Christine M. Williams · Jose M. Ordovas • \\ Dennis Lairon · John Hesketh · Georg Lietz • \\ Mike Gibney · Ben van Ommen
}

Published online: 25 June 2008

(C) The Author(s) 2008

\begin{abstract}
Nutrition science finds itself at a major crossroad. On the one hand we can continue the current path, which has resulted in some substantial advances, but also many conflicting messages which impair the trust of the general population, especially those who are motivated to improve their health through diet. The other road is uncharted and is being built over the many exciting new developments in life sciences. This new era of nutrition recognizes the complex relation between the health of the individual, its genome, and the life-long dietary exposure, and has lead to the realisation that nutrition is essentially a gene-environment interaction science. This review on the relation between genotype, diet and health is the first of a
\end{abstract}

All authors are member of The European Nutrigenomics Organisation (http://www.nugo.org).

C. M. Williams $(\square)$

Hugh Sinclair Unit of Human Nutrition,

University of Reading, Reading RG6 6AP, USA

e-mail: c.m.williams@ reading.ac.uk

J. M. Ordovas

Nutrition and Genomics Laboratory,

JM-USDA-HNRCA at Tufts University, Boston, USA

e-mail: jose.ordovas@tufts.edu

D. Lairon

INRA, 1260, INSERM, 476, University of Méditerranée

Aix-Marseille, «Nutrition Humaine et Lipides»,

Faculté de Médecine, IPHM-IFR 125,

13385 Marseille, France

e-mail: denis.lairon@univmed.fr

J. Hesketh · G. Lietz

Human Nutrition Research Centre and Institute for Cell and

Molecular Biosciences, Newcastle University,

Framlington Place, Newcastle-upon-Tyne Ne1 4HH, UK

e-mail: j.e.hesketh@newcastle.ac.uk series dealing with the major challenges in molecular nutrition, analyzing the foundations of nutrition research. With the unravelling of the human genome and the linking of its variability to a multitude of phenotypes from "healthy" to an enormously complex range of predispositions, the dietary modulation of these propensities has become an area of active research. Classical genetic approaches applied so far in medical genetics have steered away from incorporating dietary effects in their models and paradoxically, most genetic studies analyzing diet-associated phenotypes and diseases simply ignore diet. Yet, a modest but increasing number of studies are accounting for diet as a modulator of genetic associations. These range from observational cohorts to intervention studies with prospectively selected genotypes. New statistical and

G. Lietz
e-mail: georg.lietz@newcastle.ac.uk

M. Gibney

Centre for Food and Health, University College Dublin,

Dublin, Ireland

e-mail: mike.gibney@ucd.ie

B. van Ommen

Department of BioSciences, TNO-Quality of Life,

Delft, The Netherlands

e-mail: ben.vanommen@tno.nl 
bioinformatics approaches are becoming available to aid in design and evaluation of these studies. This review discusses the various approaches used and provides concrete recommendations for future research.

Keywords Nutrigenetics - Nutrigenomics - Genotype · Candidate gene

\section{Introduction: the nutrition and health equation}

For over 20 years the public health burden of diet-dependent diseases resulting from poor quality diets, excess caloric intake and sedentary lifestyles, has been the main driver for nutritional research. Rapid developments in the life sciences, especially genetics, have created significant opportunities for nutritional science. However the ability to fully exploit these, particularly in the absence of significant funding, has proved challenging. Despite many major advances, the public's perception is one of conflicting and confusing nutrition and health messages, which may be further worsened by unsubstantiated health claims for functional foods and supplements (e.g. [29, 30]), and of premature claims for personalised health [31, 33]. Against this background of a complex and rapidly growing, but still immature science base, many nutrition scientists feel unable to meet expectations for clear, evidence-based dietary recommendations for health promotion that the healthcare, functional foods and supplement providers, as well as the public, clearly require.

As well as research into the role of nutrition in disease prevention [21], there is an increasing focus on the role of nutrition in the optimisation of health at all life stages, and the related need for tools to properly quantify health in order to substantiate the beneficial impacts of dietary change. Nutritional status induces subtle changes in body function that are more difficult to detect than, for example, response to drug treatment. These small differences are, however, extremely important in determining risk of chronic disease in the longer term. Consequently, substantial effort has gone into characterising diet-health relationships through the development of circulating and other functional biomarkers. In order to capture the subtle biological effects that occur as a consequence of diet, investigators have expanded cohort sizes and attempted to control the homogeneity of study volunteers (and therefore normal genetic heterogeneity) through selection according to a range of specified healthy phenotypes. This introduces bias into the findings, with the result that outcomes from controlled intervention studies may not reflect the full range of phenotypic variability arising from diet-gene interactions that exist within, and between, populations. Recognition that an individuals nutrition-related health condition is a complex function of their genome and lifelong dietary exposure (Fig. 1), has lead to the realisation that nutrition is essentially a gene-environment interaction science. This review is the first of a series dealing with the major challenges in molecular nutrition, which touches the foundations of nutrition research. Six major topics will be reviewed: (1) genetic variation; (2) health status quantification; (3) food intake and nutritional status quantification; (4) nutritional systems biology; (5) comparative nutrigenomics and (6) technological challenges (Table 1).

This review deals with the relationship between genetics, nutrition and health. We present a number of key concepts as well as specific recommendations for future research.

\section{Genetic variation and nutrition}

Sequencing of the human genome in 2001 [57] revealed not only fewer human genes than expected (latest estimates in the region of 22,000 [6]), but also significant genetic heterogeneity within human populations. Approximately 3.4 million single nucleotide polymorphisms (SNPs) (dbSNP [11]) have been detected to date. These data have lead to revised thinking concerning the genetic basis for the evolutionary dominance of, and variation within, the human species, as well as how this information might best be exploited to benefit human health. There has been increasing recognition that the complexity of human biology is embedded in the way the genome is expressed and translated into protein and function. It is through this complexity, rather than the absolute number of human genes that gene-environment interactions and genetic polymorphisms determine individual variation in susceptibility to disease and variable responses to drugs, toxicants, physical activity and diet. The pharmaceutical industry has been quick to exploit the possibility of new drug development and personalised pharmacy based on genotypic response to drugs (pharmacogenomics), although the output from this investment is still in the early phases and the benefits actively debated [32,61].

$$
\text { health status }=\int_{\text {conception }}^{\text {now }} \text { exposure } \times \text { genome }
$$

Fig. 1 Although it is widely accepted that the health status is a result of the interaction of our environment (of which diet is a major part) and our genome, it remains a challenge to quantify the three components of the above equation. This series of reviews addressed each of the components, together with new research strategies that aid in unravelling this equation 
Table 1 Challenges of molecular nutrition research

The challenges of molecular nutrition research

1 Linking genotype to healthy nutrition

Quantification of the nutritional phenotype

Comparative nutrigenomics

Nutritional systems biology

Quantification of food intake

Technology and informatics
Genomic variation predisposes for diet related diseases and provides opportunities for tailored prevention. Inclusion of diet in genetic research is thus essential and strategies are discussed

Methods to quantify the healthy instead of the (pre)disease phenotype in relation to nutrition are introduced and discussed

The goal of model systems (yeast, c elegance, mice, ...) in comparative nutrigenomics studies is to identify the modular architecture controlling nutritional processes and identify the players that cause a system to drive away from equilibrium into instabilities and to allow the system to reach a new steady state of metabolic adaptation

Can we systematically study the molecular mechanisms underlying the metabolic adaptation at the cellular, organ and whole organism level and take it onto the level of modeling?

New analytical technologies quantify the "food metabolome" and may link the descriptive intake methods (like food frequency questionnaires) to the more exact methods used in nutritional intervention studies

Nutrition research is now embedded in a variety of technology revolutions. This requires nutrition research specific fine-tuning, standardisation, annotation, databasing and (bio)informatics. An integrated approach is presented
Nutrition researchers also recognised the potential offered by genetics and genomic-related tools in their field. Numerous articles have speculated on how the ability to identify an individual's susceptibility to diet-related diseases at an early stage, coupled with diet and lifestyle information focused on known diet-genotype-disease interactions, could increase understanding of the relationship between diet and human health [1, 17, 35, 37, 43, 46-48, 50, 52]. Genotyping of individuals participating in dietary intervention studies was rapidly incorporated into study protocols [7, 24, 42, 50, 55] as well as into many of the large ongoing cohort studies which are investigating potential diet-health relationships through observational associations [48, 58].

The concept of targeted nutritional advice, whereby dietary advice is tailored to specific subgroups, possibly based on specific genotypes, has captured the imagination of those working in both therapeutic and public health nutrition [59]. Opportunities were heralded for the food industry in functional foods and products tailored to specific genotypes [21] which could fit alongside the development of appropriate business models. The population-based "one diet fits all" approach to public health began to be questioned [10] but the potential ethical, legal and social impact of individualised nutrition [2, 20] also attracted criticism [31]. Alongside this growing interest, many findings from the early intervention and association studies began to demonstrate the full complexity of this gene-environment interaction science and the extensive research, and research funding, which would be needed to resolve the underlying science. Early in these developments it became clear that there is no such thing as a "one gene needs one diet" translation.

More than five years on from early predictions, a number of key studies have been published providing evidence of genetic heterogeneity in response to diet. A limitation of this body of literature is the conflicting nature of the reported findings, which demonstrate ambiguous effects of genotype and diet on well established risk markers for age-related diseases. In fact this parallels the similar lack of consistency of findings for the major genedisease association studies [8]; such differences arise precisely because of gene-environment interactions resulting from variable life time exposures (diet, physical activity, smoking, etc.) that exist between the different study populations. A "catch 22" situation.

It is clear that, as with other applications of genetics to human health, translation of the basic science into benefit for individuals and population health, remains as yet unfulfilled. In order to achieve this full potential, we will need to better quantify the contribution of genetics in determining variable responsiveness to diet. In order to do this future research will need to address:

- Heritability of dietary response in humans

- Study type, design and bias

- Mechanistic basis for reported diet-genotype interactions

- Mathematical approaches for analysis of effects due to multiple dietary and genetic factors

- Provision of suitable databases and data-mining tools 


\section{Approaches}

Here we present a brief summary of the four approaches used currently to study diet-gene interactions.

Candidate gene approach for diet-related diseases and their risk factors (e.g. diabetes, cardiovascular disease, obesity, osteoporosis and cancer):

- Candidate genes for risk of diet related disease (heart disease, diabetes, obesity, some cancers) may be identified by Genome Wide Association Studies (GWAS) based on case-control analysis of affected and unaffected individuals.

- Candidate genes for risk biomarkers for diet related diseases (e.g. cholesterol and heart disease, Homeostatic model assessment (HOMA) for type 2 diabetes) may be identified by GWASs within large-scale population studies in which a range of biomarkers may be available (blood cholesterol, blood pressure, bone density, waist circumference)

Such studies have the potential for identifying genes that may predispose to risk of disease (or of potential risk by virtue of biomarker measurement), but not the extent to which diet or dietary components may have interacted with the putative high-risk genotypes, since in most cases dietary exposure data is not available. The literature is riddled with conflicting outcomes [e.g. 5, 27, 34, 39, 60] that in part reflect inadequate power but, as discussed above, more often are the result of different environmental exposures within mixed high- and low-risk populations. Even when dietary data is available (and depending on the method of dietary assessment), data may be unreliable or unable to provide quantitative estimates for specific nutrients of interest. In most cases other lifestyle choices, such as smoking, exercise, alcohol intake, use of therapeutic and recreational drugs, exposure to pollutants, and measures of physiological and psychological stress, are not available and their influence on the gene-disease associations of interest, remain unquantifiable. Association studies have been replicated in different populations by some authors, for example by linking a common SNP in the insulin-induced gene 2 (INSIG2) and obesity, but this finding has not been confirmed subsequently by others [12, $23,27]$. This has been attributed to population specific differences in environmental factors and other predisposing genotypes. Other studies consistently showed that polymorphisms in the fat mass and obesity associated gene (FTO) $[18,19,62,63]$ were associated with human obesity, but unfortunately, food intake was not taken into account in these studies. Thus, although these studies support the modifying effect of environmental exposure, they also underscore the complexity of conducting size-limited studies using individuals selected solely on the basis of genotypes.

It is clear therefore that the extensive genotype information that is available to investigators studying nutrigenetics needs to be matched with comprehensive phenotypic and behavioural information, which in the case of dietary information needs to go beyond the classical use of food frequency questionnaires (FFQs). Because of the diverse and often unreliable findings, studies including FFQs have limited value as the basis for subsequent dietary intervention, which might be used for evaluating genotypespecific responses to diet.

A major disadvantage with the candidate gene studies (and diet-gene studies), and indeed with other types of studies detailed further in this review, is the single gene or a single gene-single nutrient approach, which fails to adequately categorise individuals according to genetic heterogeneity. This problem is made worse by studies focusing on single SNPs within a single gene. For a given gene, most information is included not in a single SNP but in a specific combination of genes that have evolved simultaneously over time (haplotypes). This haplotype approach is likely to be more successful [36] but analyses and further definition of relevant haplotypes are needed to identify beneficial or deleterious DNA regions, which are associated with functional disease susceptibilities. HapMap (http://www.genome.gov/) is the first step toward establishing a complete human haplotype map but information is limited, and the definition and use of individual haplotypes in population studies still uncertain [3]. It must be remembered that assignment of haplotypes is based on a probabilistic approach using algorithms, rather than functionality. Nevertheless, an example of the potential advantages of haplotype over single SNPs has been illustrated by nutrigenomics studies focusing on the IL-1 gene. Since a high degree of linkage disequilibrium exists across the IL-1 gene region, four common haplotypes have been identified in both Caucasian and African Americans, with IL-1 haplotype 1 being significantly associated with ischemic stroke, and IL-1 haplotype $2 b$ being associated with an increased risk of cancer [5, 34]. Interestingly, Chen et al. observed that the effect of individual SNPs in the promoter region on reporter gene transcription varied according to which alleles of the other occurring SNPs were present in the promoter construct. This indicated that an individual SNP can either have an up- or down-regulatory effect depending on haplotype context, and highlights the relevance of population haplotypes in the design of genetic studies, particularly for those involving gene regulatory regions.

Indeed, it might be questioned whether, by using genetic data as the primary starting point, we are searching for candidate genes in the right manner (i.e. from the gene to 
disease). Introduction of phenotypic characterisation which bring greater "functional" relevance could be beneficial. Nutrition can give clues of how to increase functional relevance. Focussing on SNPs that are on functional pathways in terms of known nutritionally-relevant metabolism, and on coherent metabolic pathways, may allow a "causal pathway" approach to the interaction of nutritional factors and multiple genetic variations [22]. Metabolomics may also be able to distinguish between "contingent" dietrelated parameters (e.g. plasma metabolites) and "structural" individual-linked parameters genotype, which better characterise the impact of gene-diet interactions and lead "backwards" to identification of candidate genes. As an example, this was studied using an NMR-based metabolomic approach linking variation in metabolite abundance to genetic polymorphisms in diabetic and normoglycemic rat models [13].

Candidate gene approach for diet-gene interactions:

- Large population studies in which genotypic, phenotypic, and dietary habits are available

- Studies in which genotyping is undertaken retrospectively on individuals who have participated in an intervention study and in whom phenotypic response to dietary changes is known.

- Dietary intervention studies where individuals are recruited prospectively according to specific polymorphism in a selected gene (or set of genes)

Data from these studies are valuable because they offer some degree of quantitation of variation in response of phenotypic markers of risk, according to specific genetic polymorphisms.

Population studies, for example the Framingham cohort, provide evidence that specific polymorphisms influence risk factors for diet-related chronic diseases [7]. However, because of the large scale of such studies, measures of dietary exposure are weak (mainly FFQs), thereby preventing definition of gene interactions at specific levels of dietary exposure. In such studies, most researchers have focused on the relationships between diet, genes, and risk markers of disease, not diet -genes and disease outcomes, although some studies have evaluated the interaction with early diagnostic markers such as carotid intima media thickness [13]. As with the candidate gene studies, results are varied and replication poor $[14,24,54,56]$, but they are valuable in identifying putative diet-genotype interactions, which could be tested further in prospective intervention or in twin studies. For instance, as part of the EU-funded Lipgene integrated project, a case control study $(n=830)$ is prospectively (7y) evaluating interaction between dietary fatty acids (measured as fatty acid biomarkers), 840 SNPs and haplotypes in 140 genes, in order to investigate genes associated with risk of the metabolic syndrome (http:// www.ucd.ie/lipgene).

Currently, within the literature the most common type of study are those which have evaluated diet-gene interactions via retrospective genotyping of subjects in which phenotypic responsiveness to a specific diet or nutrient, has already been undertaken. Dietary intervention studies in which genotyping of several genes and assessment of phenotypic response is built into the study protocol at the outset, can provide valuable information [38, 40, 44]. However, these studies are often too small, or may be subject to statistical bias because of different numbers of participants in genotypic sub-groups or are conducted amongst high-risk individuals, which are not representative of the genetic heterogeneity within the overall population [41]. There are very few dietary intervention studies in which individuals are recruited prospectively in order to study specific diet-genotype interactions [15, 40]. However, a number of studies are expected to report in the near future, including a prospective study of the impact of apo $\mathrm{E}$ genotype on blood lipid responses to fish oil fatty acids, which has also been designed to include equal numbers of both genders in each genotypic sub-group [44]. Evidence of gender-specific differences in response to diet that may be mediated in part by gender-genotype interactions is another factor that has recently been described in a few publications [4, 40, 45]. Evidence from studies involving functional proteins involved in lipid metabolism as related to cardiovascular disease (apo E), obesity (perilipin) and selenium metabolism (Selenoprotein $\mathrm{P}$ ) is indicating that the differences in response to dietary modifications associated with specific genetic mutations may affect men and women differently. Traditionally, dietary intervention studies have not recruited equal numbers of both genders. More attention should be paid to these observations, since a better understanding and greater recognition of the significance of specific disease-associated genetic polymorphisms in the context of gender is of critical public health importance.

\section{Twin studies}

Twin cohorts offer considerable potential for studying diet-genotype interactions and global impact of genomic variation in response to diet despite not being used extensively in nutrigenetics [9, 28, 49]. Studies include quantification of specific diet-gene interactions in identical and fraternal twins [e.g. folic acid and MTHFR polymorphisms) or global comparison of phenotypic responses (including metabolomics [51]), for a wide variety of risk markers in response to a specific dietary intervention (e.g. low fat vs. high fat diets). Use of a 
haplotype approach in a twins' diet-genotype study would also be of value.

Functional studies

Confirmation of the mechanistic basis of nutrient-genotype interactions in human studies is very important, but largely unexplored. Cell studies in vitro and transgenic or knockout animal models are robust tools that could be used to identify the molecular basis of diet-gene response at the cellular and whole-body metabolic level. Indeed, in terms of understanding multiple gene-gene interactions, cell and animal models may be more useful for determining the functional effects of multiple nutrient sensitive SNP interactions; thus at least establishing proof of principle. Application of nutritional systems biology, with a range of omics technologies, in cell and animal functional genomic studies may be of value in explaining the phenotypic consequences of different genotypes. However, whatever the level of technical sophistication deployed, it should be kept in mind that some polymorphisms may be responsive to dietary exposures which cannot be accurately represented in model systems.

\section{Dealing with the data}

The provision of databases and bioinformatics tools, which will help to fulfil the aims described above, are fundamental to future nutrition research. Candidate gene studies (see above) use statistical approaches, and most data published in this area to date have used standard statistical analyses. Many statistical tools are available [16] but greater focus on individual responsiveness will require a more mathematical approach and the development of suitable classification tools. Given genomic, proteomic or metabolomic parameters, the aim of these analyses will be to more accurately place an individual with respect to dietary response, although which data are used and what may be most valuable within the context of the diet needs careful consideration. Thus, in addition to new markers, specialised information mining procedures need to be developed. A general approach might be to search for "pertinent motifs" in an information stream, which has been used successfully in many other fields and should similarly be adopted by nutrition research.

Appropriate statistical analyses and models, capable of dealing with vast arrays of data, are amongst the most urgent areas for development in nutrition currently. A number of innovative approaches are being developed [25, 26]. Bayesian models complement the traditional hypothesis driven statistical approaches [53].

\section{Recommendations and concluding remarks}

Generation of genotype information is not a barrier for advancement of the field of nutrigenomics. A series of high throughput technologies are currently available, which allow in-depth genotyping of specific regions as well as relatively dense wide genome studies. The dilemma remains regarding the use of single SNPs or haplotypes, and how dense the coverage of specific regions needs to be. Continuing emphasis on the identification of functional mutations may remove the need for extensive haplotyping but this approach limits the information gathered as it will not analyse the overall interactive effects of different SNPs. In contrast a haplotype approach is not limited by present knowledge and it gathers more information, particularly therefore allowing examination of interactions between SNPs. In a functional sense the haplotype approach is therefore more comprehensive. However, identified variants may be tagged-SNPs or variants in genes of unknown function so it is then vital to confirm the precise functional effects of the identified SNPs. Moreover, nutrigenetic study design should routinely incorporate genotype selection for gene-diet interaction studies.

Major recommendations for more consistent outcomes in future studies:

(1) General study design issues:

- Larger sample sizes for both observational and interventional approaches.

- Nutritional intervention studies with prospective design for inclusion of genetically determined sub-cohorts are needed to provide clear showcases of beneficial dietary interventions for specific genotypes.

- Studies examining different ethnicities and cultural/social environments.

- Inclusion of both genders, ideally with equal numbers

(2) Diet related issues:

- Better assessment of dietary intake including development of biochemical surrogates.

- Analysis of food patterns rather than isolated nutrients.

- More standardized and defined dietary intervention protocols. The goal here will be the ability to undertake meta analyses of gene-diet interaction data as is presently done for genetic association studies.

(3) Selection of genes to be studied:

- More functional pathway oriented analyses rather than single genes. 
- Perform and repeat large scale human studies to look at multiple gene-gene and diet-gene interactions using suitable computerized tools.

- Combine single SNP/gene approach in human interventions and functional studies to identify new and potentially important gene variants.

(4) Statistics and bioinformatics:

- Novel statistical developments as present techniques may not be appropriate for these specific needs.

- Improved phenotypic response and food intake quantification. This is valid for all nutrition studies, but especially needed in nutrigenetics, where only subtle differences in response may be expected.

- Develop databases and tools which integrate available information from different human studies in dietary and genetic fields.

In conclusion, a major challenge in biomedical science is to define the contribution of dietary and genetic factors in determining susceptibility to important multi-factorial diseases. Nutritional science is grasping the opportunities offered by the explosion in genetic information and is entering a new and exciting phase in order to address this question. We are beginning to identify functionally relevant SNPs related to nutrients and to understand the needs for analysis of gene-diet interactions. Development of the field is hampered by small studies with limited dietary data and a greater collaborative effort with a focus on data sharing, will be needed. Numerous examples are now available which suggest that there are differential effects of diet on varying genotypes, but the complexity of the area demands both new tools and better studies to be applied in nutrigenetics. The first examples of dietary effects differing according to genotype have been described but the complexity of the multiple genetic factors involved and the novelty of the scientific and medical knowledge mean that the era of "personalised nutrition" is still some years away. Scientific, ethical and commercial aspects all need to be taken into account in further introducing this area. In summary, despite major advances in nutritional science and much demand from industry and parts of the public health sector, scientific and medical knowledge is too new, limited and frequently ambiguous to allow for sound personalised nutrition recommendations.

Open Access This article is distributed under the terms of the Creative Commons Attribution Noncommercial License which permits any noncommercial use, distribution, and reproduction in any medium, provided the original author(s) and source are credited.

\section{References}

1. Afman L, Muller M (2006) Nutrigenomics: from molecular nutrition to prevention of disease. J Am Diet Assoc 106:569-576

2. Bergmann MM, Bodzioch M, Bonet ML, Defoort C, Lietz G, Mathers JC (2006) Bioethics in human nutrigenomics research: European Nutrigenomics Organisation workshop report. Br J Nutr 95:1024-1027

3. Biswas NK, Dey B, Majumder PP (2007) Using HapMap data: a cautionary note. Eur J Hum Genet 15:246-249

4. Caslake MJ, Miles EA, Kofler BM, Lietz G, Curtis P, Armah CK, Kimber AC, Grew JP, Farrell L, Stannard J, Napper FL, Sala-Vila A, West AL, Mathers JC, Packard C, Williams CM, Calder PC, Minihane AM (2008) Impact of gender and genotype on cardiovascular biomarker response to fish oils (FINGEN Study). Am J Clin Nutr (in press)

5. Chen H, Wilkins LM, Aziz N, Cannings C, Wyllie DH, Bingle C, Rogus J, Beck JD, Offenbacher S, Cork MJ, Rafie-Kolpin M, Hsieh CM, Kornman KS, Duff GW (2006) Single nucleotide polymorphisms in the human interleukin-1B gene affect transcription according to haplotype context. Hum Mol Genet 15:519-529

6. Clamp M, Fry B, Kamal M, Xie X, Cuff J, Lin MF, Kellis M, Lindblad-Toh K, Lander ES (2007) Distinguishing protein-coding and noncoding genes in the human genome1. Proc Natl Acad Sci USA 104:19428-19433

7. Corella D, Lai CQ, Demissie S, Cupples LA, Manning AK, Tucker KL, Ordovas JM (2007) APOA5 gene variation modulates the effects of dietary fat intake on body mass index and obesity risk in the Framingham Heart Study. J Mol Med 85:119-128

8. Couzin J (2008) Genetic risk. With new disease genes, a bounty of questions. Science 319:1754-1755

9. Dai J, Miller AH, Bremner JD, Goldberg J, Jones L, Shallenberger L, Buckham R, Murrah NV, Veledar E, Wilson PW, Vaccarino V (2008) Adherence to the mediterranean diet is inversely associated with circulating interleukin- 6 among middleaged men: a twin study. Circulation 117:169-175

10. Darrnton-Hill I, Margetts B, Deckelbaum R (2004) Public health nutrition and genetics: implications for nutrition policy and promotion. Proc Nutr Soc 63:173-185

11. dbSNP. http://www.ncbi.nlm.nih.gov/projects/SNP/snp_summary. cgi. 2007. Ref Type: Generic

12. Dina C, Meyre D, Samson C, Tichet J, Marre M, Jouret B, Charles MA, Balkau B, Froguel P (2007) Comment on "A common genetic variant is associated with adult and childhood obesity". Science 315:187

13. Dumas ME, Wilder S, Bihoreau MT, Barton R, Fearnside J, Argoud K, D'Amato L, Wallis R, Blancher C, Keun H, Baunsgaard D, Scott J, Sidelmann UG, Nicholson J, Gauguier D (2007) Direct quantitative trait locus mapping of mammalian metabolic phenotypes in diabetic and normoglycemic rat models. Nat Genet 39(5):666-672

14. Dwyer JH, Allayee H, Dwyer KM, Fan J, Wu H, Mar R, Lusis AJ, Mehrabian M (2004) Arachidonate 5-lipoxygenase promoter genotype, dietary arachidonic acid, and atherosclerosis. N Engl J Med 350:29-37

15. Eisenach JH, Schroeder DR, Pike TL, Johnson CP, Schrage WG, Snyder EM, Johnson BD, Garovic VD, Turner ST, Joyner MJ (2006) Dietary sodium restriction and beta2-adrenergic receptor polymorphism modulate cardiovascular function in humans. J Physiol 574:955-965

16. Excoffier L, Heckel G (2006) Computer programs for population genetics data analysis: a survival guide. Nat Rev Genet 7:745758 
17. Ferguson LR, Shelling AN, Browning BL, Huebner C, Petermann I (2007) Genes, diet and inflammatory bowel disease. Mutat Res 622:70-83

18. Frayling TM, Timpson NJ, Weedon MN, Zeggini E, Freathy RM, Lindgren CM, Perry JR, Elliott KS, Lango H, Rayner NW, Shields B, Harries LW, Barrett JC, Ellard S, Groves CJ, Knight B, Patch AM, Ness AR, Ebrahim S, Lawlor DA, Ring SM, BenShlomo Y, Jarvelin MR, Sovio U, Bennett AJ, Melzer D, Ferrucci L, Loos RJ, Barroso I, Wareham NJ, Karpe F, Owen KR, Cardon LR, Walker M, Hitman GA, Palmer CN, Doney AS, Morris AD, Smith GD, Hattersley AT, McCarthy MI (2007) A common variant in the FTO gene is associated with body mass index and predisposes to childhood and adult obesity 7 . Science 316:889894

19. Freathy RM, Timpson NJ, Lawlor DA, Pouta A, Ben-Shlomo Y, Ruokonen A, Ebrahim S, Shields B, Zeggini E, Weedon MN, Lindgren CM, Lango H, Melzer D, Ferrucci L, Paolisso G, Neville MJ, Karpe F, Palmer CN, Morris AD, Elliott P, Jarvelin MR, Smith GD, McCarthy MI, Hattersley AT, Frayling TM (2008) Common variation in the FTO gene alters diabetes-related metabolic traits to the extent expected given its effect on BMI. Diabetes 57:1419-1426

20. Gorman U (2006) Ethical issues raised by personalized nutrition based on genetic information. Genes Nutr 1:13-22

21. Green MR, van der Ouderaa F (2003) Nutrigenetics: Where next for the foods industry? Pharmacogenom J 3:191-193

22. Haggarty P (2007) B-vitamins, genotype and disease causality. Proc Nutr Soc 66:539-547

23. Hall DH, Rahman T, Avery PJ, Keavney B (2006a) INSIG-2 promoter polymorphism and obesity related phenotypes: association study in 1428 members of 248 families. BMC Med Genet $7: 83$

24. Hall WL, Vafeiadou K, Hallund J, Bugel S, Reimann M, Koebnick C, Zunft H-JF, Ferrari M, Branca F, Dadd T, Talbot D, Powell J, Minihane AM, Cassidy A, Nilsson M, hlman-Wright K, Gustafsson JA, Williams CM (2006b) Soy-isoflavone-enriched foods and markers of lipid and glucose metabolism in postmenopausal women: interactions with genotype and equol production. Am J Clin Nutr 83:592-600

25. Heidema AG, Boer JMA, Nagelkerke N, Mariman ECM, van dA, Feskens EJM (2006) The challenge for genetic epidemiologists: how to analyze large numbers of SNPs in relation to complex diseases. BMC Genet 7:23

26. Heidema AG, Feskens EJM, Doevendans PAFM, Ruven HJT, van Houwelingen HC, Mariman ECM, Boer JMA (2007) Analysis of multiple SNPs in genetic association studies: comparison of three multi-locus methods to prioritize and select SNPs. Genet Epidemiol 31:910-921

27. Herbert A, Gerry NP, McQueen MB, Heid IM, Pfeufer A, Illig T, Wichmann HE, Meitinger T, Hunter D, Hu FB, Colditz G, Hinney A, Hebebrand J, Koberwitz K, Zhu X, Cooper R, Ardlie K, Lyon H, Hirschhorn JN, Laird NM, Lenburg ME, Lange C, Christman MF (2006) A common genetic variant is associated with adult and childhood obesity. Science 312:279-283

28. Hjelmborg JB, Fagnani C, Silventoinen K, McGue M, Korkeila M, Christensen K, Rissanen A, Kaprio J (2008) Genetic influences on growth traits of BMI: a longitudinal study of adult twins. Obesity 16:847-852

29. Hooper L, Thompson RL, Harrison RA, Summerbell CD, Ness AR, Moore HJ, Worthington HV, Durrington PN, Higgins JPT, Capps NE, Riemersma RA, Ebrahim SBJ, vey Smith G (2006) Risks and benefits of omega 3 fats for mortality, cardiovascular disease, and cancer: systematic review. BMJ 332:752-760

30. Howard BV, Van Horn L, Hsia J, Manson JE, Stefanick ML, Wassertheil-Smoller S, Kuller LH, LaCroix AZ, Langer RD, Lasser NL, Lewis CE, Limacher MC, Margolis KL, Mysiw WJ,
Ockene JK, Parker LM, Perri MG, Phillips L, Prentice RL, Robbins J, Rossouw JE, Sarto GE, Schatz IJ, Snetselaar LG, Stevens VJ, Tinker LF, Trevisan M, Vitolins MZ, Anderson GL, Assaf AR, Bassford T, Beresford SAA, Black HR, Brunner RL, Brzyski RG, Caan B, Chlebowski RT, Gass M, Granek I, Greenland P, Hays J, Heber D, Heiss G, Hendrix SL, Hubbell FA, Johnson KC, Kotchen JM (2006) Low-fat dietary pattern and risk of cardiovascular disease: the Women's Health Initiative Randomized Controlled Dietary Modification Trial. JAMA 295:655666

31. Janssens AC, Gwinn M, Bradley LA, Oostra BA, van Duijn CM, Khoury MJ (2008) A critical appraisal of the scientific basis of commercial genomic profiles used to assess health risks and personalize health interventions. Am J Hum Genet 82:593-599

32. Katsanis SH, Javitt G, Hudson K (2008a) Public health. A case study of personalized medicine. Science 320:53-54

33. Katsanis SH, Javitt G, Hudson K (2008b) Public health. A case study of personalized medicine1. Science 320:53-54

34. Kornman KS (2006) Interleukin 1 genetics, inflammatory mechanisms, and nutrigenetic opportunities to modulate diseases of aging. Am J Clin Nutr 83:475S-483S

35. Kussmann M, Raymond Fdr, Affolter M (2006) OMICS-driven biomarker discovery in nutrition and health. J Biotechnol 124:758-787

36. Lagou V, Scott RA, Manios Y, Chen TL, Wang G, Grammatikaki E, Kortsalioudaki C, Liarigkovinos T, Moschonis G, RomaGiannikou E, Pitsiladis YP (2008) Impact of peroxisome proliferator-activated receptors gamma and delta on adiposity in toddlers and preschoolers in the GENESIS Study. Obesity 16:913-918

37. Mathers JC (2004) The biological revolution-towards a mechanistic understanding of the impact of diet on cancer risk. Mutat Res 551:43-49

38. McNulty H, Dowey le RC, Strain JJ, Dunne A, Ward M, Molloy AM, McAnena LB, Hughes JP, Hannon-Fletcher M, Scott JM (2006) Riboflavin lowers homocysteine in individuals homozygous for the MTHFR $677 \mathrm{C} \rightarrow \mathrm{T}$ polymorphism. Circulation 113:74-80

39. Meirhaeghe A, Cottel D, Amouyel P, Dallongeville J (2005) Association between peroxisome proliferator-activated receptor gamma haplotypes and the metabolic syndrome in French men and women. Diabetes 54:3043-3048

40. Meplan C, Crosley LK, Nicol F, Beckett GJ, Howie AF, Hill KE, Horgan G, Mathers JC, Arthur JR, Hesketh JE (2007) Genetic polymorphisms in the human selenoprotein $\mathrm{P}$ gene determine the response of selenoprotein markers to selenium supplementation in a gender-specific manner (the SELGEN study). FASEB J 21:3063-3074

41. Minihane AM, Jofre-Monseny L, Olano-Martin E, Rimbach G (2007) ApoE genotype, cardiovascular risk and responsiveness to dietary fat manipulation. Proc Nutr Soc 66:183-197

42. Minihane AM, Khan S, Leigh-Firbank EC, Talmud P, Wright JW, Murphy MC, Griffin BA, Williams CM (2000) ApoE polymorphism and fish oil supplementation in subjects with an atherogenic lipoprotein phenotype. Arterioscler Thromb Vasc Biol 20:1990-1997

43. Mutch DM, Wahli W, Williamson G (2005) Nutrigenomics and nutrigenetics: the emerging faces of nutrition. FASEB J 19:16021616

44. Olano-Martin E, Abraham EC, Gill-Garrison R, Valdes AM, Grimaldi K, Tang F, Jackson KG, Williams CM, Minihane AM (2008) Influence of apoA-V gene variants on postprandial triglyceride metabolism: impact of gender. J Lipid Res 49:945-953

45. Ordovas JM (2007a) Gender, a significant factor in the cross talk between genes, environment, and health. Gend Med 4 Suppl B:S111-S122 
46. Ordovas J (2007b) Diet/genetic interactions and their effects on inflammatory markers. Nutr Rev 65:S203-S207

47. Ordovas JM, Corella D (2004) Nutritional genomics. Annu Rev Genomics Hum Genet 5:71-118

48. Ordovas JM, Corella D, Demissie S, Cupples LA, Couture P, Coltell O, Wilson PWF, Schaefer EJ, Tucker KL (2002) Dietary fat intake determines the effect of a common polymorphism in the hepatic lipase gene promoter on high-density lipoprotein metabolism: evidence of a strong dose effect in this gene-nutrient interaction in the Framingham Study. Circulation 106:2315-2321

49. Ouellet-Morin I, Boivin M, Dionne G, Lupien SJ, Arsenault L, Barr RG, Pérusse D, Tremblay RE (2008) Variations in heritability of cortisol reactivity to stress as a function of early familial adversity among 19-month-old twins. Arch Gen Psychiatry 65:211-218

50. Perez-Martinez P, Yiannakouris N, Lopez-Miranda J, Arnett D, Tsai M, Galan E, Straka R, gado-Lista J, Province M, Ruano J, Borecki I, Hixson J, Garcia-Bailo B, Perez-Jimenez F, Ordovas JM (2008) Postprandial triacylglycerol metabolism is modified by the presence of genetic variation at the perilipin (PLIN) locus in 2 white populations. Am J Clin Nutr 87:744-752

51. Pietilainen KH, Sysi-Aho M, Rissanen A, Seppänen-Laakso T, Yki-Järvinen H, Kaprio J, Oresic M (2007) Acquired obesity is associated with changes in the serum lipidomic profile independent of genetic effects-a monozygotic twin study. PLoS ONE 2:e218

52. Roche HM, Phillips C, Gibney MJ (2005) The metabolic syndrome: the crossroads of diet and genetics. Proc Nutr Soc 64:371-377

53. Rodin A, Mosley JT, Clark AG, Sing CF, Boerwinkle E (2005) Mining genetic epidemiology data with Bayesian networks application to APOE gene variation and plasma lipid levels. J Comput Biol 12:1-11

54. Santos JL, Boutin P, Verdich C, Holst C, Larsen LH, Toubro S, Dina C, Saris WH, Blaak EE, Hoffstedt J, Taylor MA, Polak J, Clement K, Langin D, Astrup A, Froguel P, Pedersen O, Sorensen TI, Martinez JA (2006) Genotype-by-nutrient interactions assessed in European obese women. A case-only study. Eur J Nutr 45:454-462

55. Shin MJ, Jang Y, Koh SJ, Chae JS, Kim OY, Lee JE, Ordovas JM, Lee JH (2006) The association of SNP276G $>$ T at adiponectin gene with circulating adiponectin and insulin resistance in response to mild weight loss. Int J Obes (Lond) 30:1702-1708

56. Sorensen TI, Boutin P, Taylor MA, Larsen LH, Verdich C, Petersen L, Holst C, Echwald SM, Dina C, Toubro S, Petersen M, Polak J, Clement K, Martinez JA, Langin D, Oppert JM, Stich V, Macdonald I, Arner P, Saris WH, Pedersen O, Astrup A, Froguel $P$ (2006) Genetic polymorphisms and weight loss in obesity: a randomised trial of hypo-energetic high- versus low-fat diets. PLoS Clin Trials 1:e12
57. Subramanian G, Adams MD, Venter JC, Broder S (2001) Implications of the human genome for understanding human biology and medicine. JAMA 286:2296-2307

58. Tai ES, Corella D, urenberg-Yap M, Cutter J, Chew SK, Tan CE, Ordovas JM (2003) Dietary fat interacts with the $-514 \mathrm{C}>\mathrm{T}$ polymorphism in the hepatic lipase gene promoter on plasma lipid profiles in a multiethnic Asian population: the 1998 Singapore National Health Survey. J Nutr 133:3399-3408

59. Trujillo E, Davis C, Milner J (2006) Nutrigenomics, proteomics, metabolomics, and the practice of dietetics. J Am Diet Assoc 106:403-413

60. Williams PT, Blanche PJ, Rawlings R, Krauss RM (2005) Concordant lipoprotein and weight responses to dietary fat change in identical twins with divergent exercise levels 1 . Am J Clin Nutr 82:181-187

61. Woodcock J (2007) The prospects for "personalized medicine" in drug development and drug therapy. Clin Pharmacol Ther 81:164-169

62. Zeggini E, Scott LJ, Saxena R, Voight BF, Marchini JL, Hu T, de Bakker PI, Abecasis GR, Almgren P, Andersen G, Ardlie K, Boström KB, Bergman RN, Bonnycastle LL, Borch-Johnsen K, Burtt NP, Chen H, Chines PS, Daly MJ, Deodhar P, Ding CJ, Doney AS, Duren WL, Elliott KS, Erdos MR, Frayling TM, Freathy RM, Gianniny L, Grallert H, Grarup N, Groves CJ, Guiducci C, Hansen T, Herder C, Hitman GA, Hughes TE, Isomaa B, Jackson AU, Jørgensen T, Kong A, Kubalanza K, Kuruvilla FG, Kuusisto J, Langenberg C, Lango H, Lauritzen T, Li Y, Lindgren CM, Lyssenko V, Marvelle AF, Meisinger C, Midthjell K, Mohlke KL, Morken MA, Morris AD, Narisu N, Nilsson P, Owen KR, Palmer CN, Payne F, Perry JR, Pettersen E, Platou C, Prokopenko I, Qi L, Qin L, Rayner NW, Rees M, Roix JJ, Sandbaek A, Shields B, Sjögren M, Steinthorsdottir V, Stringham HM, Swift AJ, Thorleifsson G, Thorsteinsdottir U, Timpson NJ, Tuomi T, Tuomilehto J, Walker M, Watanabe RM, Weedon MN, Willer CJ, Wellcome Trust Case Control Consortium, Illig T, Hveem K, Hu FB, Laakso M, Stefansson K, Pedersen O, Wareham NJ, Barroso I, Hattersley AT, Collins FS, Groop L, McCarthy MI, Boehnke M, Altshuler D (2008) Metaanalysis of genome-wide association data and large-scale replication identifies additional susceptibility loci for type 2 diabetes. Nat Genet 40:638-645

63. Zeggini E, Weedon MN, Lindgren CM, Frayling TM, Elliott KS, Lango H, Timpson NJ, Perry JR, Rayner NW, Freathy RM, Barrett JC, Shields B, Morris AP, Ellard S, Groves CJ, Harries LW, Marchini JL, Owen KR, Knight B, Cardon LR, Walker M, Hitman GA, Morris AD, Doney AS, McCarthy MI, Hattersley AT (2007) Replication of genome-wide association signals in UK samples reveals risk loci for type 2 diabetes. Science 316:13361341 